\title{
Information Systems
}

We Still Need a Feminist Approach

\author{
ALISON ADAM \\ UMIST (University of Manchester Institute of Science and Technology), UK \\ a.adam@co.umist.ac.uk
}

Abstract: This paper makes two pleas; firstly for more research on feminist inspired information systems (IS) and secondly for the IS mainstream to stop ignoring such research as it is highly relevant to its emancipatory ideals. With respect to the emerging critical or emancipatory school of IS, feminist philosophy and, in particular, feminist epistemology is used to examine the difficulties of the positivist/anti-positivist position. In addition, it is argued that the liberal version of emancipation built on the anti-positivist position adopted by critical IS is unlikely to offer true emancipation and may have an opposite effect as it leaves unexamined crucial power structures particularly in relation to women's live

\section{INTRODUCTION}

What has happened to feminist research on information systems? A thriving research area in the late 1980s and early 1990s, it appears to have largely been overtaken by interest in virtuality, gender and the Internet. For instance, although several papers explicitly on gender and information systems were delivered at the 1994 Women, Work and Computerization conference [2], the equivalent 1997 conference saw that number dwindling noticeably [11].

I offer the following as reasons to maintain that interest. Concern that women as system developers and users still face problems in the workplace remains. On a more theoretical level, developments in the theory of information systems need to be kept well within the feminist gaze. These reasons form a pressing rationale for continued interest in developing a feminist approach to information systems. This paper is offered as a 
contribution to the rekindling of interest in the theoretical side of this process; in particular toward forming a feminist critique of the emerging critical school of information systems. This critique is couched in epistemological terms i.e. relating to theories of knowledge and knowers.

Apart from a more general call to arms for feminist research in this area, the two specific points that this paper addresses is positivism/anti-positivism and emancipation in the critical IS school. Critical IS has appropriated the term 'emancipation' based on its adoption of an anti-positivist position. This term requires a feminist analysis. I will argue that such calls for emancipation may actually mask existing power structures and hence reinforce them, offering little scope for true emancipation.

The paper proceeds by introducing IS and its relation to gender studies. I describe the origins of feminist epistemology and then the problem of epistemology in the critical school of IS. Using concepts from feminist epistemology I discuss the positivist/anti-positivist debate and emancipation in regard to critical IS. I argue that, however desirable it may be, individual emancipation cannot be realised without a much more detailed understanding of the oppression experienced by different groups and what that implies for the knowledge of different groups.

\section{INFORMATION SYSTEMS AND GENDER STUDIES}

Information Systems has rapidly cast itself as a separate discipline, untying the apron strings from its mother discipline, computer science. Commentators argue that the social context of IS is as important as the technical context. This makes IS look much more like a member of the social sciences where alternative research paradigms often co-exist [5]. The critical tension emerging from a plurality of approaches is not just desirable but necessary. In building its philosophical foundations and in recognizing the value of pluralism along the way, feminist philosophy and research inspired by more general feminist principles seem to offer much scope.

There is a burgeoning literature on gender and information technologies ranging from studies of the workplace to, more recently, an upsurge of interest in virtual life [24, 9]. Such work largely remains outside the IS canon, finding its voice, rather, within education, psychology, sociology, business studies, women's studies, indeed almost anywhere but computing disciplines. It is a pity that the mainstream continues not to hear the feminist voice because there are a number of successful examples of information systems projects built with emancipatory design aims in a feminist tradition which could provide useful lessons and empirical examples for critical IS. In 
addition, although utilizing various aspects of feminist analysis, this research tradition rarely draws upon feminist philosophy explicitly (but see [1] as an exception). We need to combine the lessons of the diverse literature on gender and information technologies with aspects of feminist philosophy and bring all these to a discussion of an understanding of IS. This paper is offered as a starting point in that process.

\section{FEMINIST PHILOSOPHY AND EPISTEMOLOGY}

Feminist philosophy is one of the most theoretically developed parts of contemporary feminism and at the same time is one of the most important developments in contemporary philosophy, particularly at the radical end of the discipline. It has two jobs. The first is to criticize and re-read the established canon in philosophy, particularly as it relates to the oppression of women as all feminist theory starts off from the acknowledgement of women's near universal inferior position. Its other aim is to offer alternative theoretical positions, which rest on feminine inspired attributes such as intuition and collective responsibility rather than what are often perceived as masculine norms of individual rights and rationality. Anglo-American feminism originated from the civil rights movement of the 1960s and 1970s, which took up the struggle for women's liberation. Equal rights, equality, power struggles, inclusion, emancipation, and liberation are all terms that draw strength from this strand of feminism. Over the last twenty or so years feminist philosophy has emerged as a distinct area of enquiry. Within this, possibly the two largest topics are feminist epistemology, which sets a challenge to the traditional view of knowers and knowledge and feminist ethics which challenges traditional rights and justice based ethics [3,20].

At a time when much new IS writing locates itself within critical theory, feminist philosophy, and feminist epistemology, as major contemporary critical theories may offer much. Secondly, following the history of IS's turn to critical theory, it is clear that power, emancipation, participation, democracy and inclusion are concepts of interest to contemporary IS writers. These are concepts about which feminist epistemology has long had much to say.

There is a definite contrast to be made between feminist epistemology and a more traditional orientation, a contrast which has been highlighted by a number of feminist epistemologists $[3,6]$. In looking to explore the multiplicity of women's ways of knowing, feminist epistemologists challenge the tendency of traditional epistemology to look for a unified theory of knowledge to argue, instead, against the possibility of producing an account of knowledge which ignores the cultural context and status of 
knowers. A knowing subject who is taken to be universal disguises a hegemonic, masculine knower. Similarly, traditional epistemology assumes that knowledge is expressible in formal, written form. Feminist epistemology argues that much knowledge cannot be expressed in this way [7]. This is particularly so of tacit knowledge and more bodily forms of knowing which are often associated with women (as in the nursing example below). In a nutshell, this suggests that traditional epistemology is implicitly bound up with masculine knowers and masculine ways of knowing.

\section{FEMINIST EPISTEMOLOGY AND IS}

Feminist epistemology cannot offer an alternative epistemology for IS. This is an unrealistic and over ambitious project, at least at present. Instead, it can offer an analysis of the traditional epistemology built into IS thinking, exposing the hierarchy of knowers represented or excluded from computer systems, structures which also exclude groups other than women and thereby forming a political agenda.

My argument is that the traditional epistemology of computer systems in general, running all the way from artificial intelligence through to information systems is 'gendered' i.e. it embodies a tacit masculine norm and this requires to be rendered visible. These are arguments that have already been applied to the domain of AI [1]. For instance, the Cyc system aims to represent universal 'consensual' knowledge, i.e. the background common sense knowledge that we are all assumed to share [16]. However, the system builders do not recognize that common sense depends crucially on a multiplicity of factors such as culture, age, gender and ethnicity. Indeed, in many ways, it is anything but common. It depends on the situation of the knower, and may well not be amenable to computerized representation.

An example which shows how women's knowledge often involves bodily ways of knowing which are not readily codified or represented can be found in research on information systems designed to support nurses. Ina Wagner [22, 23] describes the tensions involved in introducing information technologies into the nursing workplace. On the one hand nursing is characterized by highly interactive, experienced based, hands on processes involving immediate contact with the patient and the patient's body. Systems such as intensive care unit monitoring technologies serve to disembed and disassociate social action from local involvement. Computerization is often seen as a strategy for making nursing more 'scientific', based on theoretical models. Such models may impose the categories of the powerful actors in the medical world, physicians, technology providers and administrators on the diverse local circumstances of the nurses' working environments. 
Feminist critiques of knowledge, although they too emphasize bodily ways of knowing, also emphasize the identity of the knowing subject as crucial. Indeed, Donna Haraway [12], in arguing for situated and embodied knowledges makes it clear that unlocatable knowledge claims are irresponsible as no one may be called into account for them. This is a theme which is rarely taken up in IS.

\section{THE PROBLEM OF EPISTEMOLOGY IN IS}

It is the relatively new critical theory school in IS associated with Hirschheim, Klein and Lyytinen [14, 13] amongst others where concerns over the positivism/anti-positivism divide find most clear expression. In looking to the social theories of Habermas they see communicative rationality as an alternative to the instrumental rationality of positivism. Within this new anti-positivist approach there lies the possibility to free individuals from oppressive and unwarranted expressions of power - the emancipatory ideal. If these ideas can be translated into the design and development of actual IS, then the systems analyst can act as emancipator rather than the harbinger of yet another inflexible information system to be imposed on unwilling users.

At one level the positivist/anti-positivist distinction is prosaic; broadly speaking it is the distinction between the methodology and ontology of the natural sciences versus those of the social sciences. I am much more interested in why IS researchers have felt the need to form such hearty articulations of the distinction in the first place [13]. Looking at this from a meta-level, I argue that the reason may lie in the emerging discipline's need to locate itself, to articulate its boundaries and particularly to create a new identity separate from the parent discipline, computer science, whose approach is largely that of positivism. In looking toward anti-positivism the new critical theorists of IS are explicitly locating their discipline as a social phenomenon to be treated as part of the social sciences in contrast to the way that computing disciplines usually ally themselves with engineering.

The method of anti-positivism is usually termed interpretivism in IS, constructivism in science and technology studies. Yet such approaches can slide into the seemingly complete relativism of postmodernism which some feminists and others regard with dismay. They claim that this denies the reality of oppression in many women's lives thus diluting the political project of feminism [17]. In any case, within the IS arena, complete social relativism fatally undermines the will toward emancipation because, if we adopt a completely relativist position, anything goes. No case for emancipation can be seen as more real than any other. Suffice it to say, for 
the present, that uncritical acceptance of anti-positivism is not necessarily desirable.

At first sight, feminist thinking would seem to fall firmly into the antipositivist camp. However there are some caveats. Firstly, as I suggest above, many feminists do not want to lose sight of some measure of realism as feminism's political project is otherwise undermined. Secondly, just taking the anti-positivist side and assuming that emancipation follows is not enough if it leaves unanalysed and untouched the social and cultural structures which maintain oppression in the first place.

\section{FEMINIST EPISTEMOLOGY AND EMANCIPATION}

The tension between preserving neutrality and alleviating oppression suggests that there are some problems with the concept of emancipation in the new critical IS. The ideal of a general approach toward emancipation may appear worthy. However, I argue that this version of emancipation leans toward a form of liberalism that is unlikely to achieve its ideals unless we direct attention to more detailed analysis of power relations within organisations and the wider society. Indeed power relations will remain unbalanced if systems designers cast themselves as the liberators or emancipators, with a privileged epistemology based on the new critical IS, storming the barricades of ignorance in emancipating the poor unfortunate users whom maybe did not realise they were candidates for emancipation.

I highlight one example of the under-analyzed liberal view of emancipation encapsulated in critical IS. Within emancipatory information systems design, as Francis Wilson [25] notes, one of the jobs of the systems facilitator is to facilitate emancipation, to ensure that every voice is heard in an 'ideal speech situation.' But this is at odds with the individual who sees their own emancipatory response as remaining silent and not engaging in dialogue. In that case, the individual chooses whether or not to enter the dialogue. This is a hypothetical ideal situation that is extremely problematic if the ways that individuals enter dialogues and have their voices heard or not is under-theorized. The power structures of who may speak and contribute remain unrecognized. For instance, feminist research suggests women's verbal contributions are often ignored or interrupted in speech. They are often seen as over-contributing to a meeting when their contribution is actually less than the equivalent masculine contribution [18, 19]. Women may not fare well in having their views heard within emancipatory approaches. Their speech situations may be far from ideal. It requires much consciousness raising to reverse traditional patterns to see and 
control these things. As an alternative, the 'study circle' concept, consciously built on feminist lines, is an approach that takes on board these ideas. It has had little or no impact on critical IS [10, 21].

Power relations vary between groups and individuals; some of us are more in need of emancipation than others. This suggests that, not only do we need to understand the fine structure of oppression, we also need to develop specific approaches based on that understanding to empower groups of users in the spirit of emancipation. There are a number of feminist studies that do take such an approach, particularly with regard to women users $[8,10,15$, 24]. Regrettably with the possible exception of the FLORENCE project these studies have been completely ignored by both the mainstream and the critical wing of IS despite their offering specific lessons in just the sort of emancipatory project which IS currently seeks [4].

Feminist epistemology argues that an assumed liberalism is inherent in unitary notions of emancipation. This is similar to Wilson's [25, p.187] critique of the development of IS design methodologies as "a microcosm of the Enlightenment legacy and its claim to emancipate humanity from the shackles of custom and dogma." Enlightenment liberalism leaves unexplored the complex manifestations of structures of power and inequality. Yet feminist epistemologists argue that these are essential in understanding epistemology, in understanding why we have a hierarchy of knowers and also, therefore, a hierarchy of knowledge, why some things are recognized and acknowledged as 'knowledge' and other things not [6].

The problem is that critical IS can, unintentionally have the effect of reifying, solidifying and making durable these inequalities by the process of representing some information and knowledge and not representing other information. This rests on the assumption that all voices have been heard and all have equal power to make their position understood. Thus, although built with the best liberal, emancipatory intentions, IS may have the opposite effect of making more real and solid those power inequalities which they have not fully analyzed and therefore have not been fully understood.

\section{CONCLUSION}

In this paper my aim has been to offer feminist philosophy, and especially feminist epistemology as a way of building a critique and offering novel approaches to epistemological problems currently of much concern to IS, particularly with respect to the emerging critical school of IS. I have focused on the positivist/anti-positivist divide and the question of emancipation that is built upon an anti-positivist position. I argue that critical IS leans toward a liberal version of emancipation implying that systems built 
under such an ethic may have the opposite effect of maintaining oppressive power structures.

I am aware that I have barely scratched the surface, noting with resignation, the way that the mainstream ignores much relevant feminist writing. I believe that the way forward in showing how feminist theory can be relevant to IS lies in more empirical research. This involves setting up and evaluating projects that take on board feminist principles in empowering users [21]. Such projects require the designers to look at women's working relations, to find techniques which will make explicit their ways of working and knowing rather than assuming that gender does not matter and that all have the same opportunity to speak. Secondly, an approach to IS projects inspired by feminism recognises that evaluation involves returning to the women in the project to evaluate the effectiveness of the project in their own terms. It is high time the mainstream of IS took heed of such projects. It may criticise them if need be but it must not ignore them.

\section{REFERENCES}

1. Adam, Alison (1998). Artificial Knowing: Gender and the Thinking Machine. London and New York: Routledge.

2. Adam, Alison, Emms, Judy, Green, Eileen and Owen, Jenny, (Eds.). (1994). IFIP Transactions A-57, Women, Work and Computerization: Breaking Old Boundaries: Building New Forms. Amsterdam: Elsevier-North Holland.

3. Alcoff, Linda and Potter, Elizabeth, (Eds.). (1993). Feminist Epistemologies. New York and London: Routledge.

4. Bjerknes, Gro and Bratteteig, Tone (1987). FLORENCE in Wonderland: System development with nurses. In Bjerknes, Gro, Ehn, Pele and Kyng, Morten, (Eds.), Computers and Democracy: a Scandinavian Challenge. Pp.279-295, Aldershot, UK: Avebury.

5. Checkland, Peter and Holwell, Sue (1998). Information, Systems and Information Systems - Making Sense of the Field. Chichester: Wiley.

6. Code, Lorraine (1993). Taking subjectivity into account. In Linda Alcoff and Elizabeth Potter, (Eds.), Feminist Epistemologies. Pp.15-48, New York and London: Routledge.

7. Dalmiya, Vrinda and Alcoff, Linda (1993). Are 'Old Wives' Tales' Justified? In Linda Alcoff and Elizabeth Potter, (Eds.), Feminist Epistemologies. Pp.217-244, New York and London: Routledge.

8. Green, Eileen (1994). Gender perspectives, office systems and organizational change, In Adam, Alison, Emms, Judy, Green, Eileen and Owen, Jenny, (Eds.), IFIP Transactions A57, Women, Work and Computerization: Breaking Old Boundaries: Building New Forms. Amsterdam: Elsevier-North Holland, 365-377.

9. Green, Eileen and Adam, Alison, (Eds.). (in press). Special issue on gender and information and communications technology, Information, Communication and Society, London and New York: Routledge.

10. Green, Eileen, Owen, Jenny, Pain, Den (Eds.). (1993). Gendered by Design? Information Technology and Office Systems. London: Taylor and Francis. 
11. Grundy, Frances, Kohler, Doris, Oechtering, Veronika and Petersen, Ute, (Eds.), (1997). Women, Work and Computerization: Spinning a Web from Past to Future. Proc. 6th IFIP WG 9.1 conference. Berlin: Springer-Verlag.

12. Haraway, Donna. (1991). Situated Knowledges: The science question in feminism and the privilege of partial perspective, In Simians, Cyborgs and Women: The Reinvention of Nature. London: Free Association Books, 183-201.

13. Hirschheim, Rudy (1985). Information Systems Epistemology: An historical perspective. In Mumford, Enid, Hirschheim, Rudi, Fitzgerald, Guy and Wood-Harper, Trevor, (Eds.), Research Methods in Information Systems: Proceedings of the IFIP WG 8.2 Colloquium Manchester Business School, 1-3 September, 1984. Amsterdam: North-Holland, 13-36.

14. Hirschheim, Rudy, Klein, Heinz and Lyytinen, Kalle (1995). Information Systems Development and Data Modeling: Conceptual and Philosophical Foundations. Cambridge, UK, New York and Melbourne: Cambridge University Press.

15. Karasti, Helena (1994). What's different in gender oriented ISD? Identifying gender oriented systems development approach, In Adam, Alison, Emms, Judy, Green, Eileen and Owen, Jenny, (Eds.), IFIP Transactions A-57, Women, Work and Computerization: Breaking Old Boundaries: Building New Forms. Amsterdam: Elsevier-North Holland, 4558.

16. Lenat, Douglas B. and Guha, R.V. (1990). Building Large Knowledge-Based Systems: Representation and Inference in the Cyc Project. Reading, Mass.: Addison-Wesley.

17. Rose, Hilary (1994). Love, Power and Language: Towards a Feminist Transformation of the Sciences. Cambridge, UK: Polity Press.

18. Spender, Dale (1980). Man Made Language. London: Routledge and Kegan Paul.

19. Tannen, Deborah (1992). You Just Don't Understand: Women and Men in Conversation. London: Virago.

20. Tong, Rosemarie (1993). Feminine and Feminist Ethics. Belmont, CA: Wadsworth.

21. Vehvilainen, Marja (1997). Gender, Expertise and Information Technology. Unpublished $\mathrm{PhD}$ dissertation, Department of Computer Science, University of Tampere, Finland.

22. Wagner, Ina (1993). Women's Voice: The case of nursing information systems, $A I$ \& Society, 7, 295-310.

23. Wagner, Ina (1994). Hard Times: The politics of women's work in computerised environments, In Adam, Alison, Emms, Judy, Green, Eileen and Owen, Jenny, (Eds.), (1994). IFIP Transactions A-57, Women, Work and Computerization: Breaking Old Boundaries: Building New Forms. Amsterdam: Elsevier-North Holland, 23-34.

24. Webster, Juliet (1996). Shaping Women's work: Gender, Employment and Information Technology. London: Longmans.

25. Wilson, Francis (1997). The truth is out there: the search for emancipatory principles in information design. Information Technology and People, 3, 187-204. 